\title{
Idea bezwarunkowego dochodu podstawowego w katolickiej myśli społecznej
}

\author{
Rafał Łętocha (iD https://orcid.org/0000-0001-7934-8373 \\ Instytut Religioznawstwa \\ Uniwersytet Jagielloński \\ e-mail: rafal.letocha@uj.edu.pl
}

\section{Abstract \\ Universal Basic Income from the Perspective of Catholic Social Thought}

A universal basic income is a government guarantee that each citizen receives a minimum income. It is also called a citizen's income, guaranteed minimum income, or basic income. The intention behind the payment is to provide enough to cover the basic costs of living and provide financial security. The concept has regained popularity as a way to offset job losses caused by technology. The incomes would be unconditional, automatic, non-withdrawable, individual, and considered a right. The main goal of the article was to consider whether the idea of universal basic oncome income is compatible with Catholic social teaching. Opinions on this matter are still divided, and there are no official statements from the Church's Magisterium on this matter.

Keywords: universal basic income, Catholic social thought

Słowa kluczowe: bezwarunkowy dochód podstawowy, katolicka nauka społeczna

Koncepcja bezwarunkowego dochodu podstawowego w ostatnich latach staje się coraz bardziej popularna, choć nie jest to pomysł, który powstał w naszych czasach. Przynajmniej od dwóch wieków mamy do czynienia z takimi postulatami pojawiającymi się w pracach ekonomistów, myślicieli politycznych czy reformatorów społecznych. Jednym z pierwszych propagatorów podobnej idei miał być angielski nauczyciel Thomas Spence. Przedstawił ją w pracy The Rights of Infants z 1797 roku. W XIX wieku ze zbliżonymi projektami wystąpił belgijski pisarz i fourierysta Joseph Charlier. W Polsce z analogicznym postulatem wyszedł August Cieszkowski. Zapewne nie bez pewnych inspiracji socjalizmem utopijnym, wskazywał on, iż każdy członek społeczności z tego tylko tytułu, iż jest jej członkiem, powinien mieć 
zapewnione podstawowe środki utrzymania, wówczas „stanie się każde indywiduum prawdziwym i konkretnym człowiekiem, bo nie będzie już pracowało aby żyć, ale będzie żyło, aby pracować"1. Jednak z zainteresowaniem takimi koncepcjami na szerszą skalę będziemy mieli do czynienia dopiero w wieku XX. Najpierw stały się popularne w latach tuż po zakończeniu I wojny światowej w środowisku brytyjskich kwakrów, później zaś od lat siedemdziesiątych zaczęto na szerszą skalę i w coraz bardziej systematyczny sposób propagować je w rozmaitych środowiskach.

Jeden z głównych zwolenników idei bezwarunkowego dochodu podstawowego Philippe van Parijs zdefiniował to pojęcie następująco:

[...] dochód wypłacany przez państwo, na stałym poziomie i regularnie, każdemu dorosłemu członkowi społeczeństwa. Jego wypłata i poziom nie zależą od tego, czy osoba jest bogata albo biedna, mieszka samotnie czy z innymi, jest chętna do pracy lub nie. W większości wersji, a na pewno w mojej, przyznawany jest on nie tylko obywatelom, ale wszystkim stałym mieszkań$\mathrm{com}^{2}$.

Na stronie internetowej Basic Income Earth Network (BIEN), najważniejszej organizacji popularyzującej tę ideę, czytamy, iż bezwarunkowy dochód podstawowy to okresowa płatność gotówkowa wypłacana wszystkim osobom bez żadnych kryteriów czy wymogów pracy. Ma ona charakter: 1) okresowy (wypłacana jest w regularnych odstępach czasu); 2) pieniężny; 3) indywidualny (wypłacana jest jednostkom, a nie gospodarstwom domowym); 4) powszechny (wypłacana jest wszystkim obywatelom, bez żadnych kryteriów dochodowych, majątkowych, wiekowych itp.); 5) bezwarunkowy (nie wiąże się z obowiązkiem podejmowania czy poszukiwania pracy) ${ }^{3}$. Maciej Szlinder do tych cech dodaje dwie kolejne, wskazując, że bezwarunkowy dochód podstawowy jest wypłacany przez państwo, czyli pochodzi z publicznego źródła, a nie od organizacji pozarządowych czy prywatnych, oraz że ma odpowiednią wysokość, która pozwala na zaspokojenie podstawowych potrzeb biologicznych i społecznych ${ }^{4}$. Wymienione tutaj cechy są o tyle istotne, że pozwalają odróżnić koncepcje bezwarunkowego dochodu podstawowego od pokrewnych, na przykład dotacji kapitałowych, negatywnego podatku dochodowego, dochodu partycypacyjnego czy minimalnego dochodu gwarantowanego. Każda z nich, choć bliska dochodowi bezwarunkowemu, nie spełnia wszystkich wymienionych powyżej kryteriów ${ }^{5}$.

W katolickiej nauce społecznej występują trzy rodzaje twierdzeń: empiryczne, filozoficzne i teologiczne. Każde $\mathrm{z}$ nich ma różny charakter obowiązywalności. Empiryczne podają materiał informacyjny oparty na analizie stanu faktycznego, filozoficzne dostarczają katolickiej nauce społecznej podstawy teoretyczno-poznawczej, podają koncepcję człowieka oraz normy jego postępowania, teologiczne

${ }^{1}$ A. Cieszkowski, Ojcze nasz, t. III, Poznań 1923, s. 206-207.

${ }_{2}^{2}$ P. van Parijs, Dochód podstawowy dla wszystkich, https://cdn.uclouvain.be/public/Exports\%20reddot/etes/documents/2009.BI_for_all_pl.pdf [dostęp: 25.04.2019].

${ }_{3}^{3}$ Basic Income Earth Network, About Basic Income, https://basicincome.org/basic-income/ [dostęp: 26.04.2019].

${ }^{4}$ M. Szlinder, Bezwarunkowy dochód podstawowy. Rewolucyjna reforma społeczeństwa XXI wieku, Warszawa 2018, s. 27.

5 Ibidem, s. 50-51. 
zaś, odwołujące się do Objawienia, mają charakter normatywny ${ }^{6}$. Zatem katolicka nauka społeczna nie może abstrahować od aktualnej sytuacji, czasu i miejsca, warunków zmieniającej się rzeczywistości. Przeciwnie, musi od tego wychodzić, dając następnie pewne wskazówki i oceniając istniejący stan na podstawie przesłanek rozumowych oraz Objawienia chrześcijańskiego. Tymczasem nie ulega przecież wątpliwości, iż w ostatnich kilkudziesięciu latach mamy do czynienia z gigantycznymi przemianami w zakresie stosunków pracy. Największy niepokój, jak się zdaje, budzi pogłębiający się kryzys zatrudnienia, który przekształcił bezrobocie w trwałe zjawisko strukturalne. Wśród jego przyczyn wymienia się zazwyczaj czynniki ekonomiczne, demograficzne, instytucjonalne czy kulturowe. Przede wszystkim jednak rewolucja naukowo-techniczna doprowadziła do przeobrażenia struktury produkcji i zatrudnienia, a co za tym idzie zmiany charakteru pracy i zmniejszenia na nią popytu. W swojej książce sprzed ponad dwudziestu lat Jeremy Rifkin podawał, iż w połowie lat dziewięćdziesiątych bezrobocie na świecie osiągnęło najwyższy poziom od czasów wielkiego kryzysu gospodarczego (ponad 800 milionów osób bez pracy lub pracujących w niepełnym wymiarze) $)^{7}$. Niektórzy snuli nawet wizję „,społeczeństwa $1 / 5$ ", w którym aktywni zawodowo stanowiliby zaledwie $20 \%$ populacji ${ }^{8}$. Wprowadzanie do gospodarki coraz bardziej zaawansowanych technologii spowodowało niemający precedensu wzrost wydajności przy znacznej redukcji zatrudnienia. Dotyczy on w zasadzie wszystkich gałęzi i grup społecznych, nie tylko robotników, ale i pracowników średniego szczebla, na których usługi również maleje popyt, co wiąże się ze spadkiem ich płac ${ }^{9}$. Rifkin należy do zwolenników koncepcji masowego bezrobocia technologicznego i tzw. końca pracy, uznających, że nie ma żadnych automatycznych mechanizmów w systemie gospodarczym, które mogłyby zagwarantować ciągłą kompensację i ponowną absorpcję pracowników przez rynek pracy. Istnienia zjawiska bezrobocia technologicznego oraz radykalnych zmian w sferze pracy nie kwestionują zazwyczaj również przedstawiciele głównego nurtu ekonomii stojący w opozycji do tez Rifkina, uważają oni jednak, iż jest to bezrobocie frykcyjne, które ma charakter przejściowy. Bezwarunkowy dochód podstawowy stanowi pewną odpowiedź na to wyzwanie, rzecz jasna niejedyną, ale bez wątpienia jest to na tyle poważna propozycja, że należy przynajmniej ją rozważyć.

Nasze rozważania należałoby zacząć od kwestii szeroko rozumianej pracy. Wydaje się bowiem, iż w tym punkcie mamy do czynienia z największą liczbą nieporozumień oraz wątpliwości. Koncepcja bezwarunkowego dochodu podstawowego wydaje się stać w fundamentalnej sprzeczności z katolicką myślą społeczną. Największy problem $\mathrm{z}$ omawianym postulatem

${ }^{6}$ P. Góralczyk, Twierdzenia empiryczne, filozoficzne i teologiczne w katolickiej nauce społecznej, „Studia Theologica Varsaviensia” 1983, nr 1, s. 75-92.

7 J. Rifkin, Koniec pracy. Schylek sity roboczej na świecie i początek ery postrynkowej, thum. E. Kania, Wrocław 2001, s. 11.

${ }^{8}$ Zob. E. Kośmicki, D. Durnaś, Czy istnieje możliwość przezwyciężenia neoliberalizmu w gospodarce i ekonomii? Podstawowe problemy wspólzawodnictwa systemowego, „Ekonomia i Środowisko” 2013, nr 2, s. 276; R.B. Reich, Praca narodów. Przygotowanie się do kapitalizmu XXI wieku, thum. L.A. Zyblikiewicz, Toruń 2000.

${ }^{9}$ J. Rifkin, op. cit., s. 11. 
polega na tym, że ignoruje on fundamentalną naturę pracy, która jest nie tylko sposobem na zdobycie środków koniecznych do przetrwania, ale stanowi konstytutywną część ludzkiej tożsamości. Mężczyźni i kobiety potrzebują pracy, aby spełniać swoje powołania jako istoty ludzkie. Zastąpienie pracy «dochodem» jest dokończeniem redukcji osoby z członka społeczeństwa do konsumenta ${ }^{10}$.

Cytowany autor powołuje się na nauczanie papieża Franciszka, zupełnie ignorując to, że pojęcie pracy nie musi być tożsame z pracą zawodową czy zarobkową oraz zatrudnieniem. Podobne opinie odnajdujemy zresztą na rozmaitych katolickich forach internetowych ${ }^{11}$.

Katolicka nauka społeczna zawsze podkreślała, iż każdy człowiek ma nie tylko prawo do pracy, ale i jej obowiązek. Argumenty na rzecz tego odnajdujemy w Piśmie Świętym, traktatach Ojców Kościoła, wypowiedziach filozofów i teologów chrześcijańskich, wreszcie także w papieskich encyklikach. Znana jest nowotestamentowa opowieść o talentach i zawarta w niej pochwała pracowitości oraz krytyka lenistwa i bezczynności. Wynika z niej, że zarówno świat zewnętrzny, jak i wszystkie wewnętrzne zdolności czy predyspozycje dane zostały człowiekowi, aby doskonalił je przez pracę. W związku z tym nie jest ona jedynie przywilejem, ale i bezwzględnym obowiązkiem człowieka. Najbardziej jednak znamienne i surowe słowa odnajdujemy w Liście św. Pawła do Tesaloniczan, w którym Apostoł autorytatywnie stwierdził: „Jeśli kto nie chce pracować, niech też i nie je” $(2$ Tes 3,10$)$. Praca została więc uznana za naturalny i właściwy sposób zdobywania środków materialnych w celu zaspokojenia swych potrzeb. Człowiek, który się od niej uchyla, nie ma moralnego prawa do utrzymania się. W Liście do Efezjan $(E f 4,28)$ św. Paweł przedstawia trzy główne cele pracy, z których ten podkreślony w Liście do Tesaloniczan zajmuje ostatnie miejsce. Wskazuje tam, że stanowi ona przede wszystkim bezpośredni środek zdobywania cnoty i unikania grzechu, a dopiero w drugiej kolejności środek zaspokojenia potrzeb gospodarczych (jej brak może skłaniać do kradzieży, jej praktykowanie to jednoczesne unikanie pokus grzechu oraz sposób zdobywania środków do udzielania jałmużny).

W świetle katolickiej nauki społecznej praca doskonali człowieka nie tylko fizycznie, lecz także moralnie. Stanowi źródło rozwoju takich cnót, jak: sumienność, obowiązkowość, odpowiedzialność, cierpliwość, wytrwałość itp. Dzięki niej człowiek może doskonalić swoje zdolności, przemienia ona bowiem nie tylko świat materialny, ale również jego samego, czyni go lepszym. Jeśli się tak nie dzieje, oznacza to, że mamy do czynienia z poważnym zaburzeniem. Papież Franciszek, odnosząc się do tych kwestii, wskazuje, że praca powinna być miejscem wielowymiarowego rozwoju osobistego. $\mathrm{Z}$ tego powodu „globalne realia społeczne współczesnego świata, poza wąskimi interesami biznesu i wątpliwą racjonalnością ekonomiczną, wymagają, aby «dążono do osiągnięcia - uznanego za priorytetowy - celu, jakim

${ }^{10}$ D. Cruz-Uribe, Opposing Universal Basic Income, https://www.patheos.com/blogs/voxnova/2017/09/03/opposing-universal-basic-income/ [dostęp: 25.04.2019]. Jeżeli nie zaznaczono inaczej, wszystkie cytaty obcojęzyczne w thumaczeniu autora artykułu.

${ }^{11}$ Universal Basic Income - Does It Work?, https://forums.catholic.com/t/universal-basic-income-does-it-work/491008 [dostęp: 23.04.2019]. 
jest dostęp wszystkich do pracy»" ${ }^{\prime 2}$. Praca ma oczywiście wymiar indywidualny, ale katolicka nauka społeczna wskazuje również na jej społeczny charakter. Praca widziana w kontekście społeczeństwa jest współpracą z ludźmi. Dzięki temu każdy ma swój wkład w tworzenie dobra wspólnego, co daje możliwość przezwyciężenia myślenia czysto indywidualistycznego. Wreszcie ma ona również wymiar religijny. Jest współuczestniczeniem człowieka w boskim dziele stwarzania. Człowiek jest niejako kontynuatorem kreacyjnego aktu Stwórcy i w pracy przejawia się znamię boskiego podobieństwa człowieka wynoszące go ponad inne stworzenia ${ }^{13}$. To wszystko decyduje o wyjątkowym charakterze pracy i o sui generis jej wywyższaniu.

Trzeba jednak pamiętać o tym, iż nie każda praca uszlachetnia, nie każdy jej rodzaj prowadzi do rozwoju osobistego oraz doskonalenia człowieka. Istnieje cały szereg zajęć charakteryzujących się monotonią, jednostajnością, które raczej ogłupiają człowieka, niż prowadzą do jego sublimacji. Katolicka nauka społeczna, mówiąc o ,godności pracy”, wskazuje, iż chodzi tutaj o pracę,

która w każdej społeczności wyraża zasadniczą godność każdego mężczyzny i każdej kobiety: pracę wybraną w sposób wolny, która włącza skutecznie pracowników, mężczyzn i kobiety, w rozwój ich wspólnoty; pracę, dzięki której pracownicy są szanowani i nie są narażeni na żaden typ dyskryminacji [...] pracę pozwalającą pracownikom na swobodne organizowanie się i dającą możliwość wypowiedzenia się; pracę, która pozostawia wystarczającą przestrzeń, by odnaleźć własne korzenie w wymiarze indywidualnym, rodzinnym i duchowym; pracę zabezpieczającą godne warunki życia pracownikom, którzy osiągnęli wiek emerytalny ${ }^{14}$.

Niestety wiele zajęć zarobkowych, z którymi mamy współcześnie do czynienia, nie spełnia tych podstawowych kryteriów. Skoro więc można uwolnić niektóre osoby od trudu związanego z pracą zarobkową, wydaje się, iż z perspektywy katolickiej nauki społecznej nie ma $\mathrm{w}$ tym nic niewłaściwego.

Stanowisko, wedle którego dawanie czegoś „za darmo” jest niekorzystne z punktu widzenia wychowawczego, psychologicznego, gospodarczego itd., nie może być uznane za zgodne z pryncypiami doktryny społecznej Kościoła, zwłaszcza w kontekście postulatów Benedykta XVI dotyczących konieczności wzbogacenia gospodarki rynkowej o zasady wypływające $\mathrm{z}$ „logiki daru”. Zdaniem papieża również w stosunkach rynkowych winna znaleźć miejsce zasada bezinteresowności.

W życiu ekonomicznym niewątpliwie potrzebny jest kontrakt, który reguluje stosunki wymiany między równoważnymi wartościami. Potrzebuje jednak również sprawiedliwych praw oraz form podziału dochodu kierowanych przez politykę, a także dzieł odzwierciedlających ducha daru. Wydaje się, że ekonomia zglobalizowana preferuje pierwszą logikę - logikę wymiany opartej na kontrakcie, ale bezpośrednio lub pośrednio wykazuje, że potrzebuje również dwóch pozostałych: logiki politycznej oraz logiki daru bez kompensaty ${ }^{15}$.

${ }^{12}$ Franciszek, Laudato si' (dalej: LS), nr 127, http://www.vatican.va/content/francesco/pl/encyclicals/documents/papa-francesco_20150524_enciclica-laudato-si.html [dostęp: 25.04.2019].

${ }_{13}$ Jan Paweł II, Laborem exercens (dalej: LE), nr 4, http://www.vatican.va/content/john-paul-ii/pl/ encyclicals/documents/hf_jp-ii_enc_14091981_laborem-exercens.html [dostęp: 25.04.2019].

${ }^{14}$ Benedykt XVI, Caritas in veritate (dalej: $\mathrm{CV}$ ), $\mathrm{nr}$ 63, http://www.vatican.va/content/benedict-xvi/ $\mathrm{pl} /$ encyclicals/documents/hf_ben-xvi_enc_20090629_caritas-in-veritate.html [dostęp: 25.04.2019].

${ }^{15}$ Ibidem, nr 37. 
Rzecz jasna papieżowi chodziło o coś innego. Pisał on bowiem o potrzebie uzupełnienia wyłącznego binomium rynek-państwo przez bardziej solidarne formy ekonomii; również bezwarunkowy dochód podstawowy mógłby się zmieścić w tych ramach i zostać uznany za przejaw nierynkowego myślenia, odejścia od logiki wymiany i kalkulowania wszystkiego oraz rozumowania w kategoriach „coś za coś”. Wówczas nie można byłoby omawianych tutaj rozwiązań postrzegać jako zdrożnych, szkodliwych, patogennych czy dezintegrujących życie społeczne. Nie do przyjęcia jest zatem perspektywa, zgodnie z którą zawsze konieczna jest jakaś rekompensata ze strony osób przyjmujących świadczenia, nawet jeżeli nie przynosiłaby ona żadnego konkretnego rezultatu czy pożytku społecznego, a miałaby charakter wysiłku bezsensownego (jak słynne Keynesowskie kopanie rowów, by następnie je zasypywać). Problem ten zauważa również ekonomista Richard Hauser, zwracając uwagę, że z jednej strony uzyskanie bezwarunkowego dochodu pozwala zrezygnować z pracy zarobkowej (jeżeli ktoś jest - rzecz jasna - zadowolony ze skromnego standardu życia), z drugiej jednak takie zabezpieczenie umożliwia pracownikowi samorealizację, podjęcie satysfakcjonującej, uszlachetniające i wartościowej działalności bez konieczności poświęcania zbyt dużej uwagi kwocie wynagrodzenia. W takich warunkach prowadzenie nieodpłatnej pracy wolontariackiej byłoby znacznie ułatwione. Ponieważ katolicka nauka społeczna zwraca na tę kwestię baczną uwagę i akcentuje potrzebę tego rodzaju działalności, wydaje się, że nie może być na tym polu żadnych dysonansów ${ }^{16}$.

Bezwarunkowy dochód podstawowy bez wątpienia oznacza wyjście poza dominującą w dzisiejszym świecie logikę workfare, według której wszelkie świadczenia otrzymywane przez jednostkę ze strony społeczeństwa lub państwa muszą być związane z obowiązkiem pracy na ich rzecz. José A. Noguera wskazuje, że zasada wzajemności może budzić wiele zastrzeżeń, a jej zwolennicy wykazują daleko idącą niekonsekwencję. Stawia on więc pytanie, czy byliby oni skłonni zabronić

na przykład życia z dochodów z rent kapitałowych? Z punktu widzenia wzajemności powinno być to całkowicie zakazane. Jeśli dziedziczysz jakiś majątek i żyjesz z dochodu z renty, którą on przynosi, nie przyczyniasz się w sposób produktywny do dobrobytu społecznego, lecz otrzymujesz dochód od społeczeństwa. Teoretycy wzajemności, co zaskakujące, skupiają się wyłącznie na drugiej stronie spektrum, na ludziach będących w najgorszej sytuacji materialnej, którzy muszą dawać coś w zamian za otrzymywanie minimalnego dochodu. Ale co z tymi znajdującymi się na szczycie piramidy społecznej? ${ }^{17}$

W świetle katolickiego nauczania trud pracy związany jest z grzechem pierworodnym. Jednakże postęp kultury materialnej, techniki, rozwój życia gospodarczego może i powinien prowadzić do zmniejszania tego trudu. Właściwym zadaniem pracy gospodarczej nie jest bowiem produkcja, ale zaspokojenie potrzeb materialnych

${ }^{16}$ R. Hauser, „Das Allgemeine Grundeinkommen”: Sein Beithag zur Verminderung von Arbeitslosigkeit und sein Verhaltnis zu dem von der Katholischen Soziallehre Geforderten Familienlohn [w:] Toward Reducing Unemployment the Proceedings of Fifth Plenary Session of the Pontifical Academy of Social Science 3-6 March 1999, M.S. Archer (red.), Vatican City 1999, s. 153-154.

${ }_{17}$ J.A. Noguera, Dochód podstawowy jako polityczny horyzont, rozmowę przeprowadził M. Szlinder, tłum. M. Szlinder, http://www.praktykateoretyczna.pl/tag/jose-a-noguera/ [dostęp: 8.05.2019]. 
człowieka. Zaspokojenie potrzeb materialnych ma człowiekowi umożliwić swobodę życia duchowego. Jak pisał Czesław Strzeszewski:

[...] można stąd uznać za pierwszy etap rozwoju cywilizacji uwolnienie ludzkości od trosk materialnych po to, aby mogła poświęcić się całkowicie rozwojowi życia duchowego. Oznaczałoby to wyzwolenie ludzkości przez cywilizację z okowów ciężarów gospodarczych, piękno stałoby się wówczas ośrodkiem życia ludzkości ${ }^{18}$. Nawet hipotetyczna sytuacja, w której cały ciężar, znój, trud pracy gospodarczej zostałby zlikwidowany za sprawą rozwoju technologicznego[,] nie byłaby równoznaczna z likwidacją pracy i związanego z nią wysiłku z perspektywy katolickiej nauki społecznej. Gdyby nawet bowiem znikł ciężar pracy fizycznej, zostałby znój pracy duchowej, intelektualnej, moralnej. [...] Praca umysłowa, naukowa, a tym bardziej praca wewnętrzna, moralna, modlitwa, wreszcie kontemplacja to rodzaje pracy, w których w coraz większym stopniu biorą udział duchowe, a w coraz mniejszym fizyczne władze człowieka ${ }^{19}$.

Podobnie rzecz się ma, jeśli rozważymy to już nie pod kątem rozwoju osobistego, ale otaczającego nas świata. Z perspektywy katolickiej nauki społecznej człowiek kontynuuje kreacyjny akt Stwórcy. Jego zadaniem jest ulepszanie świata i czynienie go bardziej przyjaznym. Tak należy rozumieć imago Dei w człowieku, to, że człowiek został stworzony na boże podobieństwo. Tymczasem również tutaj możemy obserwować liczne odchylenia od wzorca. Człowiek jest eksploatatorem ziemi i jej dóbr i za sprawą jego działalności doszło w ostatnich stuleciach do bezprecedensowych zmian o charakterze globalnym - zanieczyszczenia powietrza, wód i gleby, dewastacji przyrody oraz zaniku różnorodności biologicznej. Polityka ekstraktywizmu, rabunkowa gospodarka i nieustająca antropopresja prowadzą do postępującej degradacji i niszczenia naturalnych ekosystemów. Obowiązujący zaś ekonomistyczny paradygmat, wedle którego centralną wartość stanowi zysk, poprzez pryzmat którego waloryzuje się wszystko, powoduje, iż wszelkie inicjatywy mające ograniczyć negatywne skutki rozwoju przemysłowego nie przynoszą pożądanych rezultatów, pozostając raczej w sferze deklaracji niż realnych działań.

Katolicka nauka społeczna, dowartościowując pracę, jednocześnie zawsze odżegnywała się od jej sakralizacji. Praca ,jest «dla człowieka», a nie człowiek «dla pracy»" "20. Stąd więc nie może być mowy o uznawaniu jej za wartość samą w sobie oraz traktowaniu jej jako głównego i niezawodnego kryterium świadczącego o czyjejś wartości. Amerykański antropolog David Graeber ostrzegał, że traktując pracę jako szlachetną ex definitione, musimy uznać, iż ostateczną miarą sukcesu ludzkości jest jej zdolność do zwiększania globalnej podaży dóbr i usług.

Problem w tym, że jeśli w dalszym ciągu będziemy szli tą drogą - z czego coraz wyraźniej zdajemy sobie sprawę - z dużym prawdopodobieństwem uda nam się zniszczyć wszystko. Gigantyczna machina dłużna, która przez pięć ostatnich wieków przekształcała coraz większy odsetek mieszkańców świata w ludzi o konstrukcji moralnej konkwistadorów, dobija do kresu swoich społecznych i ekologicznych możliwości. [...] Prawdziwe pytanie brzmi, jak skręcić

\footnotetext{
18 C. Strzeszewski, Praca ludzka. Zagadnienie społeczno-moralne, Wrocław 2004, s. 167.

${ }^{19}$ Ibidem, s. 168.

${ }^{20} \mathrm{LE}, \mathrm{nr} 6$.
} 
nieco obroty machiny, wykonując krok w stronę społeczeństwa, w którym ludzie mogą żyć lepiej, pracując mniej ${ }^{21}$.

Wizja nieograniczonego rozwoju jest nie do przyjęcia z punktu widzenia nauczania społecznego Kościoła, a jak czytamy w encyklice papieża Franciszka Laudato $s i$ ': „Ludzkość wezwana jest do uświadomienia sobie konieczności zmiany stylu życia, produkcji i konsumpcji" ${ }^{22}$. Obsesyjny konsumpcjonizm charakterystyczny dla czasów nam współczesnych nazywa papież odzwierciedleniem paradygmatu technokratycznego, który sprawia, ,że wszyscy uważają się za wolnych, dopóki zachowują rzekomą wolność konsumowania. Natomiast rzeczywiście wolnymi są ci, którzy należą do mniejszości posiadającej władzę ekonomiczną i finansową"23.

Krytyka koncepcji bezwarunkowego dochodu podstawowego wynika także ze społecznego charakteru pracy, której istotą jest wymiana usług, oddawanie swojej wiedzy i sił społeczeństwa. Pojawiają się tutaj argumenty, że osoba niepodejmująca pracy zawodowej staje się jedynie biernym konsumentem, „pasażerem na gapę”, który sam biorąc, nic społeczeństwu nie daje. Jest to argument chybiony z tego powodu, że w przypadku bezwarunkowego dochodu podstawowego wszyscy są w jednakowej sytuacji. Punkt wyjścia dla każdej osoby jest ten sam. To tak jakby zarzucać niektórym, iż oddychając, korzystają z powietrza, a nie dają nic w zamian. Ponadto niepodejmowanie przez pewne grupy osób pracy zarobkowej nie oznacza, że ludzie ci tylko pasożytują na społeczeństwie, nic od siebie nie wnosząc. Wręcz przeciwnie, mogą i powinni na innych płaszczyznach wzbogacać życie społeczne poprzez swoją aktywność. Trzeba pamiętać, że mówiąc współcześnie o pracy, możemy mieć na myśli trzy różne kwestie: (1) sposób, w jaki zarabiamy pieniądze, których potrzebujemy do utrzymania się; (2) działalność niezbędną do przetrwania naszego społeczeństwa; (3) aktywność, którą uznajemy za satysfakcjonującą, ponieważ przydaje ona znaczenia i celu naszemu życiu. Te trzy sfery rzadko się ze sobą pokrywają ${ }^{24}$. Trzymanie się współczesnego ekonomistycznego paradygmatu powoduje, iż skłonni jesteśmy doceniać jedynie działalność o charakterze zarobkowym - świadczy o tym lekceważenie, z jakim podchodzi się do pracy domowej przeciwstawianej karierze zawodowej, która ma stanowić szczytowe stadium tzw. samorealizacji. Należy więc zakwestionować współczesne utożsamienie pracy jako takiej z pracą zarobkową (zatrudnieniem) przy jednoczesnym dowartościowaniu pracy wykonywanej codziennie na całym świecie niewynagradzanej finansowo, a tym samym odrzucić przekonanie, iż jedynym uczciwym i dopuszczalnym sposobem uczestniczenia w życiu społeczeństwa oraz przyczyniania się do jego pomyślności jest praca zarobkowa ${ }^{25}$.

${ }^{21}$ D. Graeber, Dlug. Pierwsze pięć tysięcy lat, tłum. B. Kuźniarz, Warszawa 2018, s. 573.

${ }^{22} L S, \mathrm{nr} 23$.

${ }^{23}$ Ibidem, nr 203.

${ }^{24}$ Por. P. Frase, Cztery przyszłości. Wizje świata po kapitalizmie, thum. M. Szlinder, Warszawa 2018, s. 42.

${ }^{25}$ S. Healy, B. Reynolds, Work for All in a World of Rapid Change: A Catholic Social Thought Perspective, s. 103, https://www.socialjustice.ie/sites/default/files/file/catholic-social-thought/chapter4.pdf [dostęp: 25.04.2019]. 
W publikacji wydanej w 1999 roku przez Papieską Akademię Nauk Społecznych czytamy o potrzebie przedefiniowania pojęcia pracy, a co za tym idzie - bezrobocia. Dominujące ich rozumienie, wypracowane w epoce przemysłowej, nie odpowiada bowiem potrzebom nowych czasów i ponowoczesnej rzeczywistości ${ }^{26}$. Przekonanie, że praca ma stanowić miała główny punkt odniesienia dla osobistej i społecznej tożsamości człowieka oraz warunek jego przynależności do społeczeństwa, w dzisiejszych czasach wyraźnie słabnie. W coraz większym stopniu z obowiązku staje się ona prawem człowieka, a bycie zatrudnionym/pracownikiem nie może być traktowane jako podstawowy i jedyny miernik ludzkiej wartości czy przesłanka do uznania danej osoby za pełnowartościowego członka społeczeństwa. W związku z tym, jak konstatuje włoski socjolog Pierpaolo Donati, stanowisko głoszone przez nowoczesną antropologię pracy kładące nacisk na pracę jako istotę człowieczeństwa należy zastąpić ideą, wedle której jest ona jednym z podstawowych wymiarów człowieka jako istoty relacyjnej ${ }^{27}$. Uwypukla on właśnie relacyjny charakter pracy rozumianej jako poszukiwanie sensu, podstawa społecznej spójności czy system wymiany regenerujący więzi społeczne ${ }^{28}$. Jego zdaniem, jeśli uznamy, że praca jest relacją społeczną, możemy uwolnić się z ram pojęciowych obowiązujących w kulturze zachodniej, wedle których stanowi ona przede wszystkim usługę instrumentalną będącą przedmiotem przywłaszczenia/kontraktu w dialektycznym układzie sługa-właściciel, proletariat-burżuazja, pracownik-pracodawca. Wówczas zaczniemy postrzegać ją jako działanie w zróżnicowanych systemach wymiany, które mają (lub mogą mieć) różne formy waluty, z rozmaitymi zasadami ekwiwalencji, przeliczania i redystrybucji. To, co zwykle nazywamy pieniędzmi, jest tylko jedną z możliwych form instrumentu kredytowego służącego do zakupu towarów i usług. Zróżnicowanie społeczeństwa niesie ze sobą zwiększenie się liczby zróżnicowanych sfer życia i działalności z ich własnymi symbolicznymi kodami transakcji oraz z ich własnymi „walutami” i zasadami wymiany. Sfery te niekoniecznie są oddzielone, ale mogą (lub mogłyby) być również powiązane lub osiągnąć porozumienie między sobą poprzez kolejne formy wymiany, które uczyniłyby towary i usługi dostępne dla wszystkich członków w wyniku konwersji poszczególnych walut obowiązujących w każdej sferze relacyjnej, gdzie praca przybiera swój specyficzny charakter. Idea obywatelskiej płacy minimalnej ma sprzyjać takiemu stanowi rzeczy. Zakładając, że osoby cieszą się minimalnym dochodem w gotówce, mogą dodać do tego dochodu całą gamę ,instrumentów kredytowych" (innych form pieniędzy), które każda osoba otrzymuje dzięki swojej działalności w różnych sferach życia i pracy, w postaci dostępu do świadczeń, towarów i usług, których nie da się przeliczyć na wartość pieniężną ${ }^{29}$.

Obaw tego rodzaju nie potwierdzają również badania prowadzone w krajach, w których wdrożono pilotażowe programy bezwarunkowego dochodu podstawowego. Pokazują one wyraźnie, iż nie ma mowy o tym, jakoby tego rodzaju świadczenia

${ }^{26}$ P. Donati, The Changing Meaning of Work (Secularlzed vs Humanistic) and Its Implications for the New Society [w:] Toward Reducing Unemployment..., op. cit., s. 287-291.

${ }^{27}$ Ibidem, s. 293-294.

28 Ibidem, s. 316.

${ }^{29}$ Ibidem, s. 319-320. 
miały zniechęcać ludzi do podejmowania pracy, rozleniwiać ich, zmniejszać aktywność, kreatywność, promować wyłącznie postawy roszczeniowe. Wręcz przeciwnie, w świetle chociażby doświadczeń fińskich okazuje się, iż beneficjenci tych świadczeń pracowali tyle samo lub więcej niż przedstawiciele grupy kontrolnej, która ich nie otrzymywała. Dodatkowo osoby z grupy testowej doświadczyły znacznie mniej problemów związanych ze zdrowiem, stresem i koncentracją niż te z grupy kontrolnej. Stały się też bardziej pewne co do swojej przyszłości oraz możliwości radzenia sobie z problemami ${ }^{30}$. Podobnie rzecz wyglądała w przypadku eksperymentu przeprowadzonego w stanie Madhya Pradesh w Indiach. Jest to jak dotąd jedyny w pełni naukowo przygotowany i zrealizowany projekt bezwarunkowego dochodu podstawowego. Trwał niemal półtora roku. Objęto nim dwadzieścia wiosek o zbliżonej charakterystyce i populacji, a całym przedsięwzięciem kierował Guy Standing. Po zakończeniu programu okazało się, że w grupie eksperymentalnej zanotowano wzrost aktywności zawodowej, zwiększyła się liczba łącznych godzin pracy będących sumą pracy najemnej, pracy na własny rachunek oraz pracy domowej. W gospodarstwach wzrosła liczba maszyn i inwentarza, zaczęto też tworzyć kooperatywy. Ponadto eksperyment wykazał, iż dochód podstawowy wpłynął pozytywnie na stan zadłużenia i oszczędności mieszkańców, wzrósł stan higieny w gospodarstwach domowych, poprawiła się dieta mieszkańców oraz ich zdrowie, zwiększyła się liczba godzin spędzanych przez dzieci w szkole oraz polepszyły się ich wyniki w nauce ${ }^{31}$. Generalnie eksperymenty te wyraźnie pokazują, że jedyną grupą, która w związku z istnieniem bezwarunkowego dochodu podstawowego pracuje mniej (jako osoby zatrudnione) są zamężne kobiety z małymi dziećmi ${ }^{32}$. Z punktu widzenia katolickiej nauki społecznej jawi się to jako niewątpliwy walor.

Warto na koniec nadmienić, iż odnajdujemy rzecz jasna także postaci i środowiska związane z Kościołem katolickim, które są przychylnie nastawione do idei bezwarunkowego dochodu podstawowego. Jednym z najbardziej konsekwentnych propagatorów tej idei jest profesor ekonomii z St. John's University Charles M.A. Clark. W swoich licznych publikacjach na ten temat konsekwentnie wskazuje on, iż katolicka nauka społeczna wyraźnie faworyzuje równiejsze społeczeństwo. Oznacza to, jego zdaniem, że katolicy są zobowiązani do odkrywania i promowania polityki gospodarczej, która doprowadzi do zmniejszenia ubóstwa oraz nierówności, promowania większej mobilności oraz inkluzji społecznej. Według Clarka bezwarunkowy dochód podstawowy sprzyja wielu pozytywnym i pożądanym zjawiskom społecznym. Miałby on stymulować chociażby podejmowanie niepłatnych lub niskopłatnych prac, nieodzownych jednak z punktu widzenia społeczeństwa, przyczyniających się do jego rozwoju i właściwego funkcjonowania. Mógłby też odgrywać istotną rolę w polityce obrony i promowania wartości rodzinnych, które w dzisiejszych czasach w dużej mierze ugięły się pod naciskiem wszechobecnych

30 V. Tangemann, Study: Universal Basic Income Won't Make People Work Less. People Who Received Basic Income Experienced Fewer Health Problems, https://futurism.com/study-universal-basic-income-finland-work-less [dostęp: 22.04.2019].

31 M. Szlinder, op. cit., s. 232-233.

32 D. Clemmer, The Church and Basic Income Proposals, https://www.osvnews.com/2019/01/04/ the-church-and-basic-income-proposals/ [dostęp: 23.04.2019]. 
i zaborczych reguł rynkowych ${ }^{33}$. Ksiądz Joseph Ogbonnaya z Marquette University podkreśla natomiast, iż katolicka nauka społeczna promuje przede wszystkim dobro ludzkie. Podobnie bezwarunkowy dochód podstawowy ma na celu promowanie dobrego samopoczucia człowieka i nawet jeśli postulat ten nie jest zawarty explicite w katolickim nauczaniu społecznym, to stanowi on środek skutecznie wdrażający większość jej wytycznych ${ }^{34}$. Podobnie dyrektor katolickiego stowarzyszenia Jesuit Forum for Social Faith and Justice, Anne-Marie Jackson, jednoznacznie stwierdziła, iż idea bezwarunkowego dochodu podstawowego jest całkowicie zgodna z katolickim nauczaniem społecznym. Porównała przy tym pieniądze do nawozu, który rozrzucony po polu działa z korzyścią dla wszystkich ${ }^{35}$. Wypowiedź ta pojawiła się zresztą w konkretnych okolicznościach - w związku z przerwaniem w Ontario pilotażowego programu wypłacania bezwarunkowego dochodu podstawowego, który obejmował cztery tysiące osób i miał trwać jeszcze kilkanaście miesięcy. Stało się to po objęciu stanowiska premiera prowincji przez Douga Forda, reprezentującego Progresywno-Konserwatywną Partię Ontario, który zresztą w kampanii wyborczej kilkakrotnie obiecywał, że program nie zostanie zamknięty. Argumenty przeciwników programu sprowadzały się do tego, iż program nie spełnia swoich zadań, a ludziom nie żyje się lepiej. Seán Healy i Brigid Reynolds rozważali, co przemawia za wprowadzeniem bezwarunkowego dochodu podstawowego, i we wnioskach wskazali na kilka zasadniczych kwestii. Rozwiązanie to ich zdaniem jest najlepszą alternatywą dla współczesnego systemu, ponieważ: jest przyjazne pracy i zatrudnieniu; eliminuje pułapki ubóstwa i pułapki bezrobocia; promuje sprawiedliwość i zapewnia wszystkim przynajmniej minimalne dochody; równomierniej rozkłada ciężar opodatkowania; traktuje mężczyzn i kobiety jednakowo; jest prosty i przejrzysty; jest skuteczny; nagradza ignorowane przez gospodarkę rynkową rodzaje pracy, na przykład prace domowe, wychowywanie dzieci itp.; ułatwia kontynuowanie edukacji i szkolenie siły roboczej; stawia czoła zmianom w gospodarce światowej ${ }^{36}$. Nawet przywoływany już wcześniej Richard Hauser, odrzucając bezwarunkowy dochód podstawowy i opowiadając się za dochodem warunkowym związanym z posiadaniem rodziny (Familienbezogenes Bedingtes Grundeinkommen), nie czyni tego jednak z powodu niezgodności tego pierwszego z pryncypiami katolickiej nauki społecznej. Wskazuje natomiast, iż jego zdaniem w dłuższej perspektywie doprowadziłby on do znacznego zwiększenia obciążeń podatkowych, co prawdopodobnie obniżyłoby wskaźnik inwestycji, a tym samym skutkowałoby niższym wzrostem gospodarczym. A więc decydujące są tutaj kwestie ekonomiczne, gospodarcze i przewidywana przez Hausera niemożność podołania przez państwo w dłuższym okresie obciążeniom, które niosłoby ze sobą wprowadzenie bezwarunkowego dochodu gwarantowanego ${ }^{37}$.

33 C.M.A. Clark, K. Kavanagh, Basic Income, Inequality, and Unemployment: Rethinking the Linkage between Work and Welfare, „Journal of Economic Issues” 1996, nr 2, s. 404-405.

${ }^{34}$ M. Swan, Basic Income Can't Be Ignored, Says Vatican Expert, https://www.catholicregister.org/ item/26256-basic-income-cant-be-ignored-says-vatican-expert [dostęp: 24.04.2019].

${ }_{35}$ Idem, Catholic Social Teaching Supports Basic Income’s Aim, https://www.catholicregister.org/ item/28909-catholic-social-teaching-supports-basic-income-s-aim [dostęp: 20.04.2019].

36 S. Healy, B. Reynolds, op. cit., s. 120.

37 R. Hauser, op. cit., s. 161-162, 164. 
Już kilkadziesiąt lat temu Czesław Strzeszewski pisał, iż człowiek współczesny znajduje się pod przemożną presją cywilizacji, techniki, nieustannego pośpiechu, huku motorów, błysku neonów, reklam, radia, telewizji, kina. Nie ma od tego ucieczki. Mamy coraz mniej czasu na skupienie, zadumę i jesteśmy coraz bardziej zagubieni w gąszczu informacji i bodźców docierających do nas ze wszystkich stron ${ }^{38}$. Od tego czasu zjawiska te uległy ogromnej intensyfikacji, przede wszystkim w związku $\mathrm{z}$ bezprecedensowym rozwojem mediów cyfrowych. Czas wolny nie stanowi w tej sytuacji jedynie zbędnego luksusu i okazji do lenistwa, lecz ma służyć higienie psychicznej współczesnego człowieka narażonego na zbyt wiele bodźców. Ma „umożliwić mu znalezienie samego siebie w rozgwarze życia. Ma on za zadanie umożliwienie człowiekowi pełnego rozwoju osobowego. Stosunek człowieka do świata nie może być wyłącznie celowy, pragmatyczny, musi uwzględniać rozrywkę i artyzm. Skoro zaspokojenie potrzeb materialnych wymaga coraz mniejszego wysiłku całej ludzkości, czas wolny od pracy winien być wykorzystany na zaktywizowanie tych sił, które nie są już potrzebne w życiu zawodowym" ${ }^{39}$. Nigdy chyba w dziejach ludzkości nie pracowano tak dużo i niestrudzenie jak w epoce przemysłowej. Kardynał Joseph Höffner widzi przyczynę tego w przecenianiu przez współczesnego człowieka standardu życiowego i wskazuje, iż tego rodzaju podejście do pracy, z jakim mamy do czynienia współcześnie, $w$ innych czasach uznane byłoby za szaleństwo ${ }^{40}$. Przez wiele stuleci obchodzono bowiem w świecie chrześcijańskim około pięćdziesięciu świąt rocznie (oprócz niedziel), co powodowało, iż tydzień roboczy znacznie się skracał. Dopiero w XIX wieku doszło do ich likwidacji, a tym samym do wydłużenia tygodnia pracy. Paradoksem jest fakt, iż mimo że w związku z automatyzacją od lat systematycznie wzrasta produktywność, to jednocześnie wydłuża się czas pracy. Ekonomistka z Uniwersytetu Harvarda, Juliet Schor, wskazuje na przykład, iż od 1948 roku do lat 90. XX wieku w USA produktywność wzrosła ponad dwukrotnie, co oznacza ni mniej ni więcej, że ludzie są w stanie zapracować na standard życia z 1948 roku w czasie o połowie krótszym. Mimo to przeciętny czas pracy Amerykanina wydłużył się o 163 godziny rocznie, a czas odpoczynku po pracy oraz przebywania na płatnym urlopie i zwolnieniu chorobowym zmniejszył się o ponad jedną trzeciąa ${ }^{41}$ Tendencje te dotąd nie uległy zmianie. Ostatnie badania prowadzone w USA pokazują, że ludzie pracują ciężej niż kiedykolwiek wcześniej, bez dodatkowych wynagrodzeń, a to pociąga za sobą rozmaite negatywne skutki ${ }^{42}$. Amerykański badacz z Uniwersytetu Stanforda, Jeffrey Pfeffer, podaje w swojej książce, że stres w pracy kosztuje amerykańskich pracowników ponad 300 miliardów rocznie (leczenie chorób przewlekłych), a liczba zgonów z tego powodu każdego roku może rosnąć o 120 tysięcy. Wskazuje on, że długie godziny spędzane w pracy, brak równowagi między pracą

${ }^{38}$ C. Strzeszewski, op. cit., s. 320.

${ }^{39}$ Ibidem.

40 J. Höffner, Chrześcijańska nauka społeczna, tłum. S. Pyszka, Kraków [s.a.], s. 114.

${ }^{41}$ J. Schor, The Overworked American. The Unexpected Decline of Leisure, New York 1991, s. 1-5, $29-32$.

42 D. Schawbel, Jeffrey Pfeffer On His New Book "Dying for a Paycheck", http://www.personalbrandingblog.com/jeffrey-pfeffer-new-book-dying-paycheck/ [dostęp: 26.10.2018]. 
a życiem rodzinnym oraz niepewność ekonomiczna są toksyczne dla pracowników, niszczące fizyczne i psychiczne zdrowie ludzi, a także w ostatecznym rozrachunku niekorzystne dla wydajności firmy ${ }^{43}$. Warto w tym kontekście pochylić się nad zjawiskiem, które David Graeber nazwał „,bullshit jobs” - pod pojęciem tym rozumie powstające masowo bezcelowe prace różnego rodzaju, służące wyłącznie temu, aby ludzie mieli zajęcie ${ }^{44}$. Zdaniem amerykańskiego antropologa są one główną przyczyną narastającej frustracji, powodują cierpienie, stres, wywołują poczucie bezsensu, albowiem ludzie doskonale zdają sobie sprawę z tego, iż wykonują czynności społecznie bezużyteczne. Ludzkie szczęście zaś, jak konstatuje Graeber, „zawsze powiązane jest z poczuciem wywierania wpływu na świat; poczuciem, które większość ludzi, mówiąc o swojej pracy, wyraża w języku wartości społecznej" 45 . Rozpowszechnienie się i utrwalenie w świecie zachodnim traktowania pracy jako formy samoumartwienia, dyscypliny, drogi do doskonałości, postrzeganie jej jako wartości autonomicznej, służącej wychowaniu człowieka, mającej charakter zarówno kary, jak i odkupienia, wiąże on przede wszystkim z pojawieniem się protestanckiej etyki pracy, zwłaszcza w duchu purytańskim ${ }^{46}$.

\section{Bibliografia}

Basic Income Earth Network, About Basic Income, https://basicincome.org/basic-income/ [dostęp: 26.04.2019].

Benedykt XVI, Caritas in veritate, http://www.vatican.va/content/benedict-xvi/pl/encyclicals/documents/hf_ben-xvi_enc_20090629_caritas-in-veritate.html [dostęp: 25.04.2019].

Cieszkowski A., Ojcze nasz, t. III, Poznań 1923.

Clark C.M.A., Kavanagh K., Basic Income, Inequality, and Unemployment: Rethinking the Linkage between Work and Welfare, „Journal of Economic Issues” 1996, nr 2, s. 399-406.

Clemmer D., The Church and Basic Income Proposals, https://www.osvnews.com/2019/01/04/thechurch-and-basic-income-proposals/ [dostęp: 23.04.2019].

Cruz-Uribe D., Opposing Universal Basic Income, https://www.patheos.com/blogs/voxnova/ 2017/09/03/opposing-universal-basic-income/ [dostęp: 25.04.2019].

Donati P., The Changing Meaning of Work (Secularlzed vs Humanistic) and Its Implications for the New Society [w:] Toward Reducing Unemployment the Proceedings of Fifth Plenary Session of the Pontifical Academy of Social Science 3-6 March 1999, M.S. Archer (red.), Vatican City 1999, s. 287-324.

Franciszek, Laudato si', http://www.vatican.va/content/francesco/pl/encyclicals/documents/papafrancesco_20150524_enciclica-laudato-si.html [dostęp: 25.04.2019].

Frase P., Cztery przyszłości. Wizje świata po kapitalizmie, tłum. M. Szlinder, Warszawa 2018.

Góralczyk P., Twierdzenia empiryczne, filozoficzne i teologiczne w katolickiej nauce społecznej, „Studia Theologica Varsaviensia” 1983, nr 1, s. 75-92.

Graeber D., Dlug. Pierwsze pięć tysięcy lat, tłum. B. Kuźniarz, Warszawa 2018.

43 J. Pfeffer, Dying for Paycheck. How Modern Management Harm Employee Health and Company Performance - and What Can We Do About It, New York 2018.

${ }^{44}$ D. Graeber, Praca bez sensu. Teoria, thum. M. Denderski, Warszawa 2018, s. 12.

45 Ibidem, s. 381.

${ }^{46}$ Ibidem, s. 354-357. 
Graeber D., Praca bez sensu. Teoria, tłum. M. Denderski, Warszawa 2018

Hauser R., „Das Allgemeine Grundeinkommen”: Sein Beithag zur Verminderung von Arbeitslosigkeit und sein Verhaltnis zu dem von der Katholischen Soziallehre Geforderten Familienlohn [w:] Toward Reducing Unemployment the Proceedings of Fifth Plenary Session of the Pontifical Academy of Social Science 3-6 March 1999, M.S. Archer (red.), Vatican City 1999, s. 143-166.

Healy S., Reynolds B., Work for All in a World of Rapid Change: A Catholic Social Thought Perspective, https://www.socialjustice.ie/sites/default/files/file/catholic-social-thought/chapter4. pdf [dostęp: 25.04.2019].

Höffner J., Chrześcijańska nauka społeczna, tłum. S. Pyszka, Kraków [s.a.].

Jan Paweł II, Laborem exercens, http://www.vatican.va/content/john-paul-ii/pl/encyclicals/documents/hf_jp-ii_enc_14091981_laborem-exercens.html [dostęp: 25.04.2019].

Kośmicki E., Durnaś D., Czy istnieje możliwość przezwyciężenia neoliberalizmu $w$ gospodarce i ekonomii? Podstawowe problemy wspótzawodnictwa systemowego, „Ekonomia i Środowisko” 2013, nr 2, s. 276-284.

Noguera J.A., Dochód podstawowy jako polityczny horyzont, rozmowę przeprowadził M. Szlinder, thum. M. Szlinder, http://www.praktykateoretyczna.pl/tag/jose-a-noguera/ [dostęp: 8.05.2019].

Parijs P. van, Dochód podstawowy dla wszystkich, https://cdn.uclouvain.be/public/Exports\%20reddot/etes/documents/2009.BI_for_all_pl.pdf [dostęp: 25.04.2019].

Pfeffer J., Dying for Paycheck. How Modern Management Harm Employee Health and Company Performance - and What Can We Do About It, New York 2018.

Reich R.B., Praca narodów. Przygotowanie się do kapitalizmu XXI wieku, thum. L.A. Zyblikiewicz, Toruń 2000.

Rifkin J., Koniec pracy. Schyłek sity roboczej na świecie i początek ery postrynkowej, thum. E. Kania, Wrocław 2001.

Schawbel D., Jeffrey Pfeffer On His New Book "Dying for a Paycheck", http://www.personalbrandingblog.com/jeffrey-pfeffer-new-book-dying-paycheck/ [dostęp: 26.10.2018].

Schor J., The Overworked American. The Unexpected Decline of Leisure, New York 1991

Swan M., Basic Income Can't Be Ignored, Says Vatican Expert, https://www.catholicregister.org/ item/26256-basic-income-cant-be-ignored-says-vatican-expert [dostęp: 24.04.2019].

Strzeszewski C., Praca ludzka. Zagadnienie społeczno-moralne, Wrocław 2004.

Swan M., Catholic Social Teaching Supports Basic Income's Aim, https://www.catholicregister.org/ item/28909-catholic-social-teaching-supports-basic-income-s-aim [dostęp: 24.04.2019].

Szlinder M., Bezwarunkowy dochód podstawowy. Rewolucyjna reforma społeczeństwa XXI wieku, Warszawa 2018.

Tangemann V., Study: Universal Basic Income Won't Make People Work Less. People Who Received Basic Income Experienced Fewer Health Problems, https://futurism.com/study-universalbasic-income-finland-work-less [dostęp: 22.04.2019].

Universal Basic Income - Does It Work?, https://forums.catholic.com/t/universal-basic-incomedoes-it-work/491008 [dostęp: 23.04.2019]. 